\title{
Comparative assessment of "Wara" (Local Cheese) produced using three natural additives as coagulants
}

\author{
Orhevba, B. A.* and Taiwo, A. D. \\ Department of Agricultural and Bioresources Engineering, Federal University of Technology, PMB 65, Minna, Niger \\ State, Nigeria. \\ ${ }^{*}$ Corresponding author. Email: borhevba@yahoo.com
}

Copyright (@ 2016 Orhevba and Taiwo. This article remains permanently open access under the terms of the Creative Commons Attribution License 4.0, which permits unrestricted use, distribution, and reproduction in any medium, provided the original work is properly cited.

Received 23rd October, 2016; Accepted 30th November, 2016

\begin{abstract}
This study was carried out to assess the nutritional and organoleptic properties of "Wara" - local cheese prepared by addition of some selected coagulants. All experiments were carried out under standard laboratory conditions. Three variants of cheese were made using three natural coagulants which include Calotropis procera (CC), Moringa oleifera (MC) and lemon juice (LC). These were further divided into two based on the quantity of coagulant used, each making a total of six subdivisions; $\mathrm{CC}_{1}, \mathrm{CC}_{2}, \mathrm{MC}_{1}, \mathrm{MC}_{2}, \mathrm{LC}_{1}$ and $\mathrm{LC}_{2}$. The following properties were determined: fat, protein, moisture content, carbohydrate, calcium, Ash, general appearance, texture, color and taste. These were analyzed based on the various coagulants used. It was observed that the organoleptic properties such as, texture, colour, taste and general appearance were affected by the quantity of each coagulant added to each of the samples; the Calotropis procera (CC), Moringa oleifera (MC) cheese samples were preferred to the lemon juice cheese samples based on the response from the sensory evaluation carried out. The results of the proximate analysis showed differences in fat, protein, moisture content, carbohydrate, ash and calcium contents of the different samples prepared. The Calotropis procera (CC) cheese samples gave better values in terms of fat, calcium and ash contents; while the Moringa oleifera cheese samples had good results in terms of carbohydrate content. The quantity of each coagulant added to each of the samples also affected the carbohydrate content; the more the quantity of coagulant used, the lower the carbohydrate content. From the results obtained, it can be concluded that Moringa oleifera and Calotropis procera are promising and generally desirable local coagulants in cheese processing.
\end{abstract}

Key words: Cheese, coagulants, Moringa oleifera, lemon, Calotropis procera.

\section{INTRODUCTION}

Cheese is made in almost every country in the world with the existence of more than 2,000 varieties ( $O^{\prime}$ Connor, 1993). It provides an ideal medium for preservation of valuable nutrients in milk and is an excellent source of protein, fat, minerals, vitamins, and essential amino acids. The ingredients used for cheese processing are milk, starter, and coagulants (Beresford et al., 2001). The general steps of cheese manufacturing involve heat treatment of milk, addition of starter or coagulant, and removal of whey. Slight changes are, however, made from time to time depending on the variety of the cheese (O' Connor, 1993, Adegoke et al., 1992). Cheese is a solid milk product from the milk of goat, cow, sheep and other mammals by curdling the milk using a combination of rennet and acidification (Buckman, 2003). Cheese production is common to households in many developing countries, which provides a useful service in increasing the shelf-life of valuable human food- stuff like milk (Turkoglu et al., 2001).

In Nigeria, milk production is mainly done by the Fulani nomadic people, who are pastoralists involved in the rearing of cattle, moving from one location to another in search of green pasture. Due to lack of refrigeration facilities, the Fulani women process the surplus fresh milk into a soft, unipen cheese called "warankasi" or "wara" in short term. The wara cheese is widely consumed at home and sold in the market in South-western Nigeria. The cheese is usually stored in a mixture of whey at room 
temperature $\left(28^{\circ} \mathrm{C}\right)$. Under these storage conditions, wara is highly perishable and has a shelf life of 2 to 3 days.

One of the modern technologies employed in the curdling of milk is the use of commercial preparations of lactic acid bacterial cultures and milk coagulants, which are usually imported. Production of lactic acid by the starter flora during manufacture of cheese results in a decrease in the $\mathrm{pH}$ of milk and this, in combination with cooking and stirring, promotes syneresis of the curd and expulsion of whey (Walstra, 1993). The coagulants used for wara processing include the leaves and stem extracts of Sodom apple (Calotoropis procera), lemon juice and Moringa oleifera. The Moringa olifeira extract is preferred over the extracts of pawpaw and Sodom apple because Moringa oleifera processed cheese has a sweeter flavour compared to the cheese processed with pawpaw leaf extracts (O' Connor, 1993). Moringa oleifera is one of the world's most useful plants; it is cultivated in the tropics for its leaves, fruits and root and for a variety of food and medicinal purposes (Fahey, 2005). The immature green pods are probably the most valued and widely used of all its parts as it contains all the essential amino acids. The tree has been advocated as an outstanding indigenous source of highly digestible protein, calcium, Vitamin C and carotenoids which is suitable for utilization in many developing regions of the world. It provides an ideal medium for preservation of valuable nutrients in milk and is an excellent source of protein, fat, minerals, vitamins, and essential amino acids (Adegoke et al., 1992, Adetunji, et al., 2008).

Raw milk easily becomes sour when it is stored for a long period at high ambient temperatures prevalent in tropical and subtropical countries. This is because the inherent lactic acid bacteria and contaminating microorganisms from storage vessels or the environment break down the lactose in milk into lactic acid. High storage temperatures result in faster microbial growth and hence faster milk spoilage.

The treatment of any fluid with the common inorganic coagulants has some certain disadvantages among which are the cost of chemicals (especially for developing nations). Aluminium Sulfate is the most commonly used coagulant in the developing countries. Studies have linked it to the development of neurological diseases (e.g. pre-senile dementia or Alzheimer's disease) due to the presence of aluminium ions in the drinking water (Johnson et al., 2001).

However, Moringa oleifera is one of the natural coagulants that have been tested over the years as an alternative to the use of inorganic and synthetic coagulants. It has been found to be effective for high turbid waters. Moringa oleifera as a coagulating aid has been tested in various studies, and researchers found that when Alumen is used together with Moringa oleifera as a coagulant, better performance of removal of color and turbidity is achieved (Dahot, 1998). Cheese making with natural coagulants has reduced the level of milk wastages and associated diseases which result from inorganic coagulants.

Cheese is nutritionally important to the body. It also helps in reducing the quantity of raw milk wastage, because the milk which would have been lost as a result of the spoilage is converted to cheese. Also, the artificial coagulants that are used in the preparation of cheese (wara) have been linked to some diseases, thus the need to investigate some natural coagulants as a means of obtaining safe and healthy cheese.

\section{MATERIALS AND METHODS}

\section{Sample Collection}

A clean bowl was used to collect three litres of fresh cow milk from Gidan Kwano Village. $50 \mathrm{~g}$ of Moringa Oleifera seed and fresh Calotropis procera stems were obtained from trees within the University campus, Gidan kwanu, while 10 strains of lemon fruits were purchased from Kure market, Minna, Niger State.

\section{Production of Cheese using Calotropis Procera as Coagulant}

The fresh stems of Calotropis procera were washed and a sharp knife was used to make incisions on the stems. Slight pressure was applied to the stems to extract juice from it. The extracted juice was then collected in a clean bowl. One litre of fresh cow milk was put in an aluminium pot and $2.5 \mathrm{ml}$ of the extracted calotropis procera juice was added. The contents in the pot were allowed to boil for about 30 minutes at $100^{\circ} \mathrm{C}$. The mixture was stirred continuously on the fire until it coagulated and the curd had separated from the whey. The pot was removed from heat and the curd and whey were poured into the raffia basket to drain the cheese for about 5 to $8 \mathrm{mins}$ and to give it the desired shape i.e. the cylindrical shape of the raffia basket (this shape makes the cheese look attractive). The produced cheese was labeled sample $\mathrm{CC}_{1}$. Another sample $\mathrm{CC}_{2}$ was also produced with the addition of $5 \mathrm{ml}$ of calotropis procera extract juice.

\section{Production of Cheese using Moringa Oleifera as Coagulant}

Fifty grams of dry Moringa oleifera seeds was grounded and soaked in 0.4 litres of water. The resulting solution was allowed to stand for an hour. One litre of fresh cow milk was heated in an aluminium pot at $100^{\circ} \mathrm{C} .50 \mathrm{ml}$ of Moringa Oleifera seed solution was added to the warmed milk. The resulting mixture was left on the fire (low heat) for 30 minutes until it coagulated. The produced cheese 
Table 1. Nutritional Properties of the six cheese samples.

\begin{tabular}{lcccccc}
\hline Cheese Type & Fat (\%) & Protein (\%) & Carbohydrate (\%) & Ash (\%) & $\begin{array}{c}\text { Moisture } \\
\text { Content (\%) }\end{array}$ & Calcium (\%) \\
\hline Calotropis Cheese $\left(\mathrm{CC}_{1}\right)$ & $64.50^{\mathrm{a}}$ & $14.40^{\mathrm{a}}$ & $3.10^{\mathrm{c}}$ & $2.00^{\mathrm{b}}$ & $47.37^{\mathrm{c}}$ & $32.14^{\mathrm{a}}$ \\
Calotropis Cheese $\left(\mathrm{CC}_{2}\right)$ & $64.50^{\mathrm{a}}$ & $12.78^{\mathrm{b}}$ & $2.72^{\mathrm{c}}$ & $3.5^{\mathrm{a}}$ & $54.23^{\mathrm{b}}$ & $32.14^{\mathrm{a}}$ \\
Moringa Cheese $\left(\mathrm{MC}_{1}\right)$ & $59.50^{\mathrm{ab}}$ & $12.08^{\mathrm{b}}$ & $13.41^{\mathrm{a}}$ & $2.00^{\mathrm{b}}$ & $48.00^{\mathrm{c}}$ & $29.76^{\mathrm{a}}$ \\
Moringa Cheese $\left(\mathrm{MC}_{2}\right)$ & $62.50^{\mathrm{a}}$ & $12.30^{\mathrm{b}}$ & $8.70^{\mathrm{b}}$ & $1.50^{\mathrm{bc}}$ & $41.89^{\mathrm{d}}$ & $29.76^{\mathrm{a}}$ \\
Lemon Cheese $\left(\mathrm{LC}_{1}\right)$ & $59.0^{\mathrm{ab}}$ & $15.23^{\mathrm{a}}$ & $9.48^{\mathrm{b}}$ & $2.00^{\mathrm{b}}$ & $39.55^{\mathrm{d}}$ & $19.18^{\mathrm{b}}$ \\
Lemon Cheese $\left(\mathrm{LC}_{2}\right)$ & $62.10^{\mathrm{a}}$ & $11.03^{\mathrm{bc}}$ & $7.69^{\mathrm{bc}}$ & $1.00^{\mathrm{cd}}$ & $63.92^{\mathrm{a}}$ & $19.05^{\mathrm{b}}$ \\
\hline
\end{tabular}

Similar superscripts in columns are not significantly different $(p<0.05)$.

Table 2. Results of questionnaire on the organoleptic assessments.

\begin{tabular}{lcccc}
\hline Sample & Texture & General appearance & Flavour and Taste & Colour \\
\hline $\mathrm{MC}_{1}$ & $3.8^{\mathrm{a}}$ & $3.3^{\mathrm{a}}$ & $4.6^{\mathrm{a}}$ & $2.7^{\mathrm{ab}}$ \\
$\mathrm{MC}_{2}$ & $4.0^{\mathrm{a}}$ & $3.2^{\mathrm{a}}$ & $3.8^{\mathrm{b}}$ & $3.3^{\mathrm{a}}$ \\
$\mathrm{LC}_{1}$ & $3.4^{\mathrm{a}}$ & $2.6^{\mathrm{a}}$ & $2.5^{\mathrm{c}}$ & $2.2^{\mathrm{bc}}$ \\
$\mathrm{LC}_{2}$ & $1.7^{\mathrm{b}}$ & $2.5^{\mathrm{a}}$ & $1.4^{\mathrm{d}}$ & $1.8^{\mathrm{c}}$ \\
$\mathrm{CC}_{1}$ & $3.9^{\mathrm{a}}$ & $2.4^{\mathrm{a}}$ & $4.2^{\mathrm{ab}}$ & $1.7^{\mathrm{c}}$ \\
$\mathrm{CC}^{2}$ & $3.9^{\mathrm{a}}$ & $3.8^{\mathrm{a}}$ & $3.7^{\mathrm{b}}$ & $3.1^{\mathrm{ab}}$ \\
\hline
\end{tabular}

Similar superscripts in columns are not significantly different $(p<0.05)$. Note: Outcome from questionnaires. $\mathrm{MC}_{1}$, Moringa oleifera cheese sample 1 [50ml], $\mathrm{MC}_{2}$, Moringa oleifera cheese sample $2[100 \mathrm{ml}]$, LC, Lemon cheese sample 1 [50ml], LC2, Lemon cheese sample 2 $[100 \mathrm{ml}], \mathrm{CC}_{1}$, Calotropis procera cheese sample 1 [2.5ml], CC 2 , Calotropis procera cheese sample $2[5 \mathrm{ml}]$.

was labeled sample $\mathrm{MC}_{1}$. Another sample $\mathrm{MC}_{2}$ was also produced with the addition of $100 \mathrm{ml}$ of Moringa oleifera seed solution.

\section{Production of Cheese using Lemon Juice as Coagulant}

Ten strains of lemon fruits were squeezed and sieved with filter cloth to obtain lemon juice. One litre of milk was poured into an aluminium pot, placed on low heat and allowed to heat for about 30 minutes to a temperature of $100^{\circ} \mathrm{C}$. $50 \mathrm{ml}$ of lemon juice was added to the milk and left to continue heating. Continuous stirring was done until the mixture coagulated and was visible to separate curd from whey. The pot was removed from heat and the curd and whey were poured into a raffia basket which drained the whey off the cheese and gave it the desired shape. The produced cheese was labeled sample LC $_{1}$. Another sample $\mathrm{LC}_{2}$ was also produced with the addition of $100 \mathrm{ml}$ of lemon juice.

\section{Proximate and Mineral Analysis}

The proximate composition of the samples were determined according to the method described by AOAC (2012), while the calcium content was determined using the method described by lbitoye (2005).

\section{Organoleptic Assessment}

Sensory evaluation form was prepared for the assessment of organoleptic properties of the "wara" samples. The 5 point hedonic scale was used. Ten people were picked randomly within the University community to serve as panelists. The responses obtained from the panelists after assessing each sample was taken so as to know their preference for the sample on an average. This was achieved using descriptive statistics.

The comparison of mean responses of these samples was done using the tool; Analysis of Variance (ANOVA), and the significant mean comparison were separated with Duncan Multiple Range test (DMRT). These tools were used because the mean of more than two groups (six samples) were to be compared.

\section{RESULTS AND DISCUSSIONS}

The results obtained are as presented in Tables 1 and 2 . The results of the proximate and mineral analyses showed differences in fat, protein, moisture, carbohydrate 


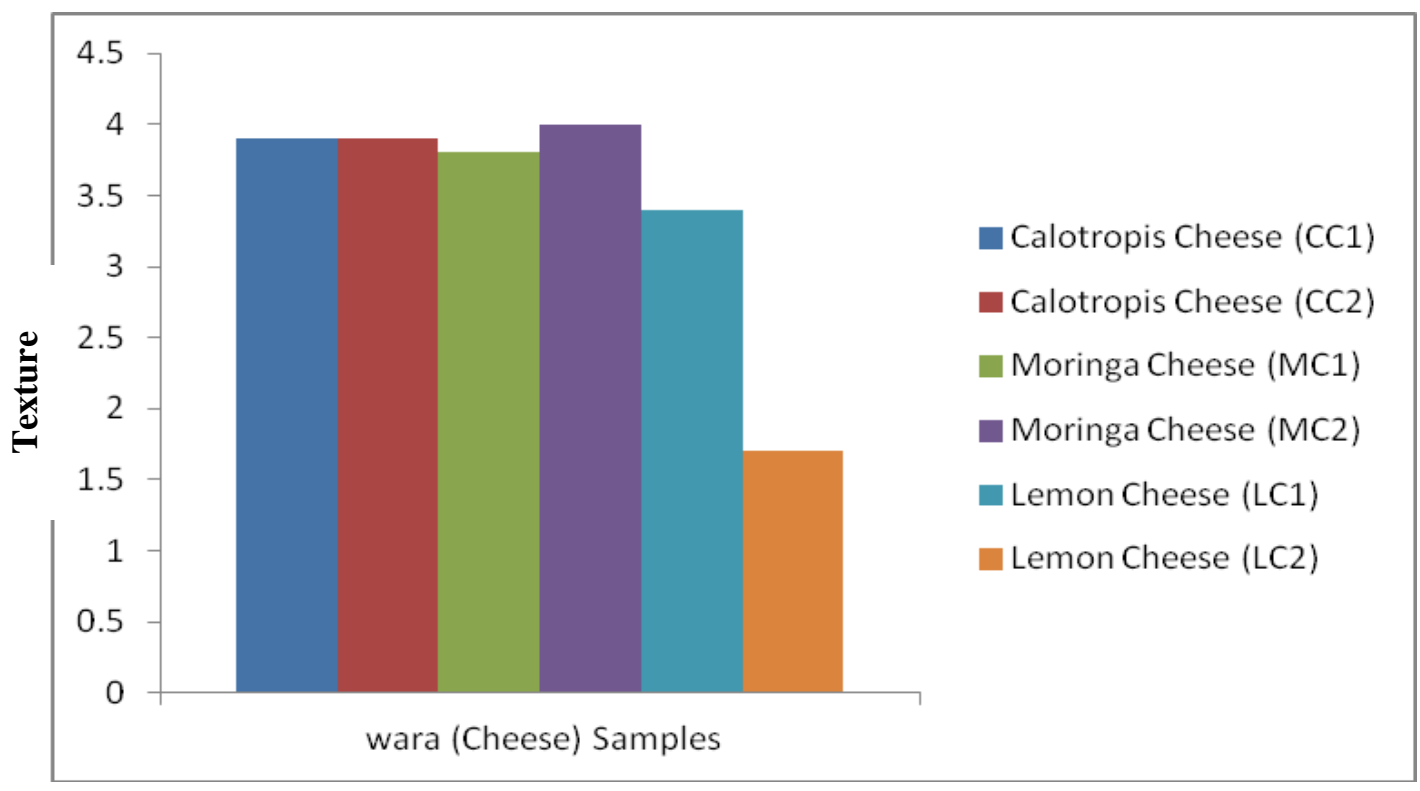

Figure 1. Texture (Organoleptic Properties) Evaluation of the Cheese Samples.

ash and calcium contents of Calotropis procera, Moringa oleifera and lemon juice coagulated cheeses. Out of the six samples prepared, Calotropis procera yielded highest value $(64.50 \%)$ of fat content, which is higher than the value $(31.45 \%)$ reported by Belewu, 2001, Johnson et al. 2001. The higher fat content in Calotropis Procera cheese could be as a result of its high coagulating strength.

The composition of protein in the Calotropis procera sample was similar to the one obtained by Alalade and Adeneye, 2006 but lower than the value $(45.3 \%)$ reported by Johnson et al. (2001). The moisture content of lemon cheese, $L_{2}(63.92 \%)$ was higher than those of Calotropis procera and Moringa Oleifera cheese samples $\left(\mathrm{MC}_{1}, \mathrm{MC}_{2}, \mathrm{CC}_{1}\right.$ and $\left.\mathrm{CC}_{2}\right)$; this may be due to the higher coagulating strength of Calotropis procera and Moringa Oleifera. Higher moisture content could favour the growth and proliferation of microorganisms as reported by Adegoke et al. 1992; thus reducing the shelf-life of cheese. The carbohydrate content (13.41\%) of Moringa Oleifera cheese, $\mathrm{MC}_{1}$ was the highest. It was observed that, increasing the quantity of each coagulant added to the milk by $50 \%$, led to a resulting decrease in carbohydrate content of the cheese samples; Moringa Oleifera cheese samples reduced from 13.41 in $\mathrm{MC}_{1}$ to $8.70 \%$ in $\mathrm{MC}_{2}$; Calotropis procera cheese samples reduced from $3.10 \%$ in $\mathrm{CC}_{1}$ to $2.72 \%$ in $\mathrm{CC}_{2}$; while the lemon juice cheese samples reduced from $9.48 \%$ in $\mathrm{LC}_{1}$ to $7.69 \%$ in $\mathrm{LC}_{2}$. For calcium content, Calotropis procera coagulated cheese had the highest value $(32.14 \%)$, followed by Moringa Oleifera coagulated cheese $(29.76 \%)$ while lemon juice coagulated cheese had the least value (19.05\%).

It was also discovered that the calcium content of the cheese samples remained constant with increase in quantity of each coagulant added (Table 1). The values of ash content obtained from the six cheese samples were very close to each other, but Calotropis procera coagulated cheese had the highest value (3.50\%).

However, Moringa oleifera and Calotropis Procera coagulated cheeses are preferred (Figures 1 to 4 ) as discovered from respondents to sensory evaluation and the retention of their nutritional values such as fat, protein, moisture content, calcium and carbohydrate (Table 1). The lemon juice coagulated cheese was sour to taste. This is due to the Citric Acid present in the lemon juice, though, it is a natural preservative used in foods.

\section{Organoleptic Properties}

Figures 1 to 4 graphically illustrate the effects of each coagulant on the organoleptic properties (texture, general appearance, flavour and taste, colour) of the cheese samples. It also shows that volume variation of each coagulant has resultant variations on the organoleptic properties. Plates 1 to 3 shows the cheese samples prepared with the different coagulants.

\section{Texture}

There were significant differences in the mean responses obtained for the samples $(p<0.05)$. $\mathrm{MC}_{2}, \mathrm{CC}_{1}, \mathrm{CC}_{2}, \mathrm{MC}_{1}$ and $L C_{1}$ were not significantly different from each other, which means that, on the average, they have similar texture ranging from slightly firm (3) to firm (4), but were 


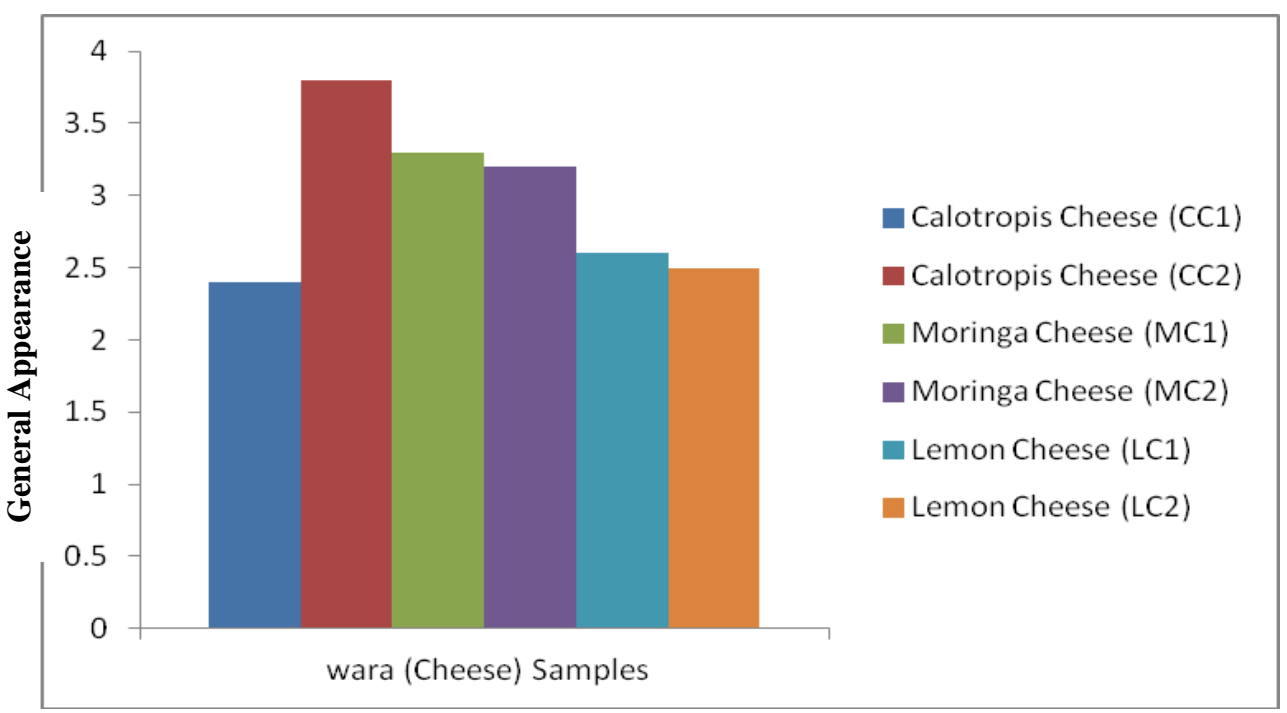

Figure 2. General Appearance (Organoleptic Properties) Evaluation of the Cheese Samples.

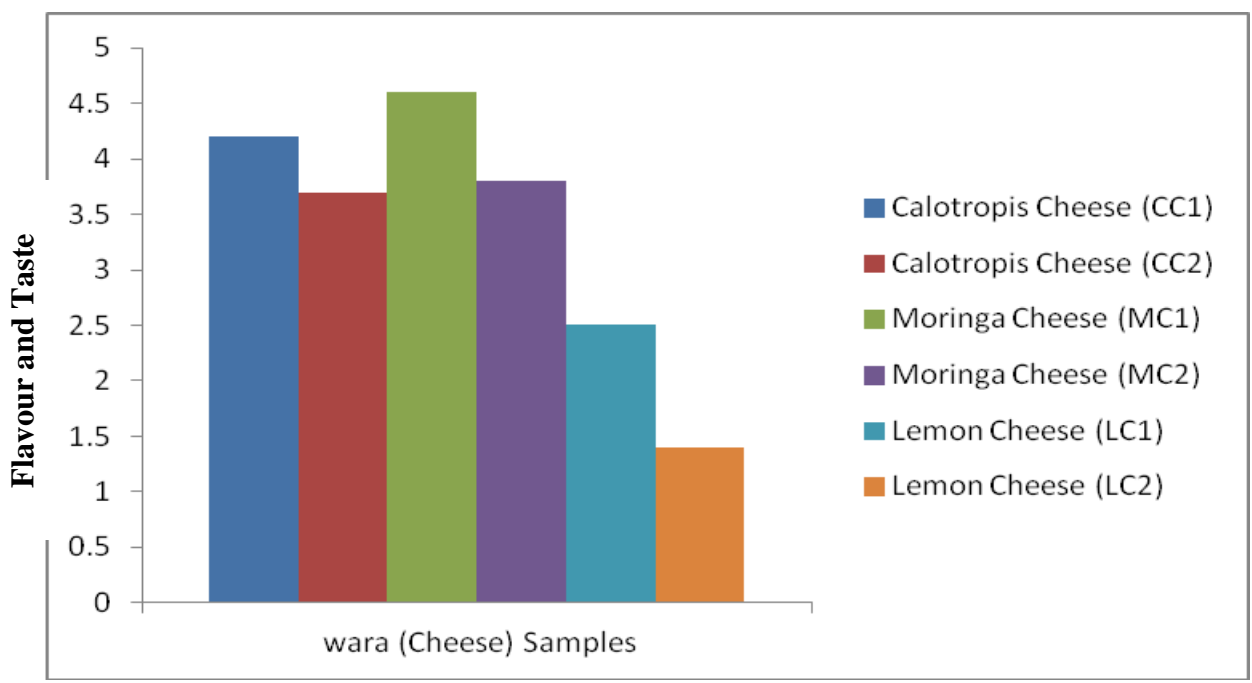

Figure 3. Flavour and Taste (Organoleptic Properties) Evaluation of the Cheese Samples.

significantly different from that of $\mathrm{LC}_{2}$ with the texture between very soft (1) and soft (2) - close to soft (2).

\section{General appearance}

There were no significant differences in the mean response to general appearance between the samples ( $p$ $>0.05$ ). This means that they have similar appearance, between moderately unattractive (2) to moderately attractive. Though not significantly different by observation, $\mathrm{CC}_{1}$ has its appearance close to moderately unattractive and others close to attractive, except $\mathrm{CC}_{2}$ which is close to moderately attractive.

\section{Flavour and Taste}

There were significant differences in the mean responses between the samples $(p<0.05)$. The flavor and taste of $M C_{1}$ and $C_{1}$ were between almost sweet (4) and very sweet (5) to taste respectively but were not significantly different from each other. They $\left(\mathrm{MC}_{1}\right.$ and $\left.\mathrm{CC}_{1}\right)$ were significantly different from $L C_{1}$ and $L_{2}$. $C_{1}$ was not significantly different from $M C_{1}$ as well as $M_{2}$ and $C_{2}$ (with almost sweet taste) but were significantly different from $L C_{1}$ and $L C_{2}$. $L C_{1}$ was significantly different from $\mathrm{LC}_{2}$ in flavor and taste. $\mathrm{LC}_{1}$ has almost fairly sweet taste while $\mathrm{LC}_{1}$ was almost very sour. 


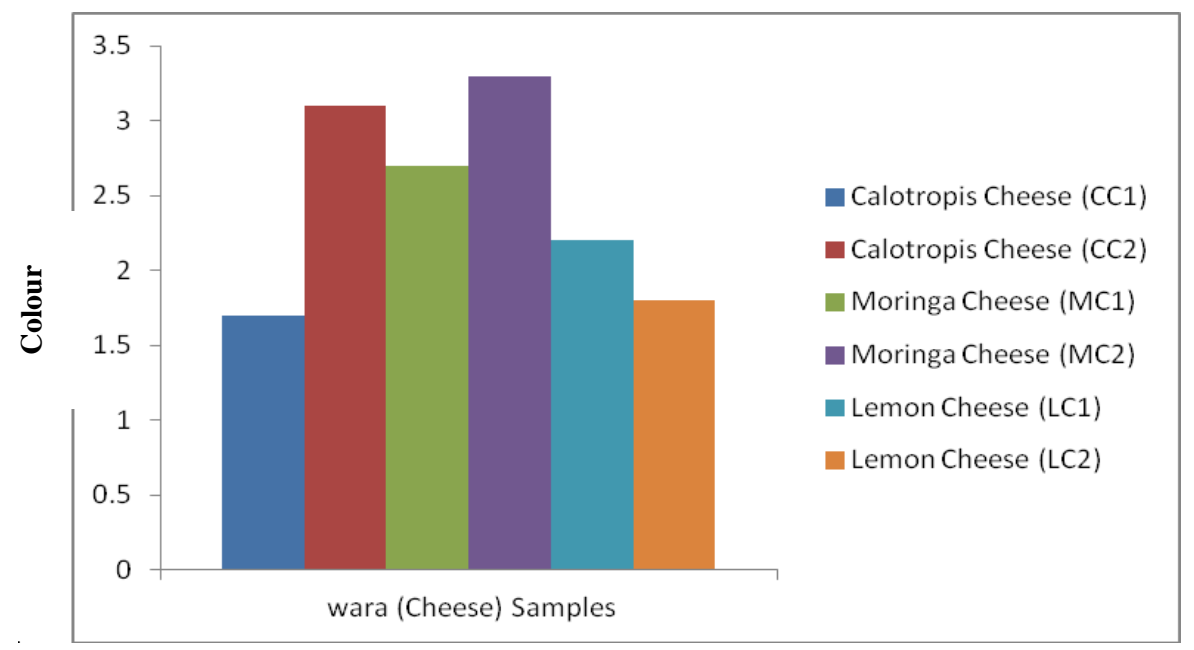

Figure 4. Colour (Organoleptic Properties) Evaluation of the Cheese Samples.

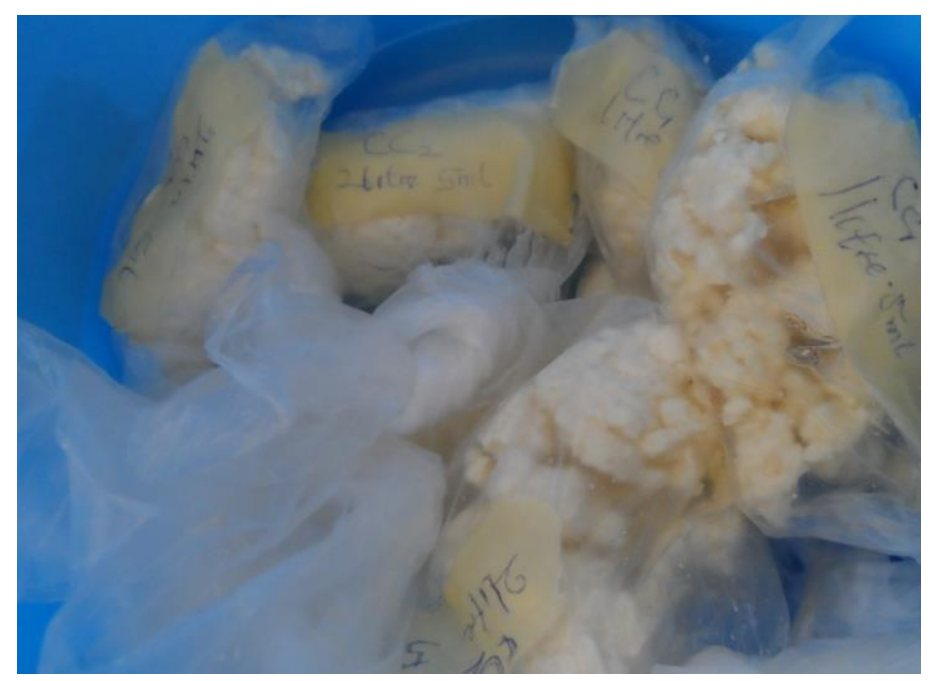

Plate 1. Calotropis Procera coagulated Cheese.

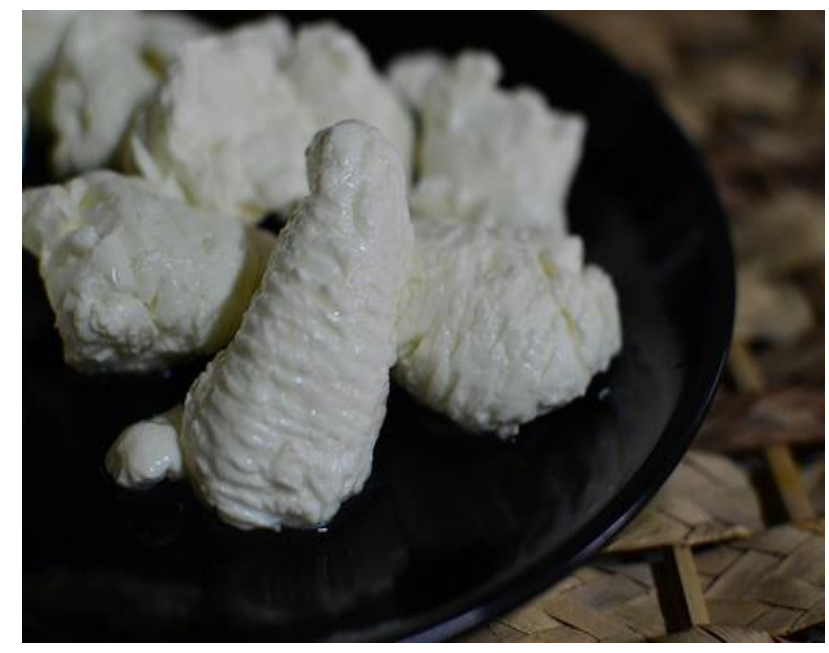

Plate 2. Moringa Oleifera coagulated Cheese. 


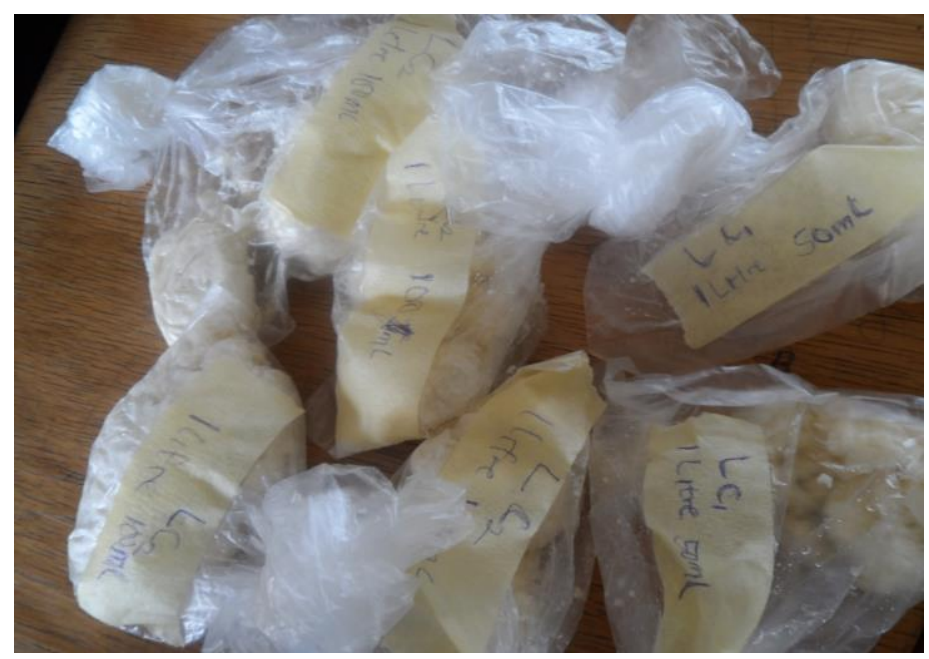

Plate 3. Lemon juice coagulated Cheese.

\section{Colour}

From Table 2, it can be seen that there were significant differences in the mean responses of the respondents to the colour of the samples as perceived $(p<0.05)$. The colour of samples $\mathrm{MC}_{2}, \mathrm{CC}_{2}$ and $\mathrm{MOC}_{1}$ which were almost white were not significantly different from each other. The almost dull white of $\mathrm{LC}_{1}$ was not significantly different from the almost white colour of $\mathrm{CC}_{2}$ and $\mathrm{MC}_{1}$ as well as almost dull white colour of $\mathrm{LC}_{2}$ and $\mathrm{CC}_{1}$, which means they were not significantly different from each other. The almost white colour of $\mathrm{MC}_{2}$ was significantly different from the almost dull white colour of $\mathrm{LC}_{1}, \mathrm{LC}_{2}$ and $\mathrm{CC}_{1}$.

\section{CONFLICT OF INTEREST}

The authors declare that they have no conflict of interest.

\section{Conclusion}

The comparative study of the nutritional and organoleptic properties of the varieties of cheese produced with fruit juice and seed extracts of the three plants, suggested and confirmed that Moringa Oleifera and calotropis procera were promising and generally desirable local coagulants in cheese processing. From this study it was observed that the nutritional and organoleptic properties of the cheese produced based on the type and quantity of coagulant added varied slightly from each other.

\section{REFERENCES}

Adegoke, G. O., Nse, E. N., \& Akanni, O. O. (1992). Effects of heat, processing time and $\mathrm{pH}$ on the microflora, aflatoxin content and storability of "wara", a soft, white cheese. Die Nahrung. 36,259- 264.

Adetunji, V. O., Alonge, D. V., Singh, R. K., \& Chen, J. (2008). Production of wara, a West African soft cheese using lemon juice as a coagulant. LWT-Food Sci. Technol., 41, 331-336.

Alalade, O. A., \& Adeneye, J. A. (2006). The effect of storage period on the chemical composition and coliform microflora of wara cheese. Int. J. of Dairy Sci., 1(2), 126-130.

AOAC. (2012). Official Methods of Analysis (18ed.). (Horwitz, W. Ed.) Gaitherberg, USA: Association of Official Analytical Chemists.

Belewu, M. A. (2001). Nutritional and rheological evaluation of West African soft cheese made from plant coagulant (Calotropis procera) during storage. J. of Food Technol. Afr., 6(3), 93-95.

Beresford, T. P., Fitzsimons, N. A., Brennan, N. L., \& Cogan, T. M. (2001). Recent advances in cheese microbiology. Int. Dairy J., 11(4-7), 259-274.

Buckman, R. (2003). Milk Production and its uses. Retrieved from www.oldandsold.com/article07/nu-48.shtml.

Dahot, M. U. (1998). Antimicrobial activity of small protein of Moringa Oleifera leaves. Journal of the Islamic Academy of Science, 11(1), 6p.

Fahey, J. (2005). Moringa oleifera: A Review of the Medical Evidence for Its Nutritional Therapeutic, and Prophylactic Properties. Part 1. Trees for Life Journal. [Accessed on Feb. 24, 2016]. Available at: https://www.tfljournal.org/article.php? story $=20051201124931586$

Ibitoye, A. A. (2005) Laboratory Manual on Basic Methods in Plant Analysis. Foladave Publishing Co., Akure, Nigeria. 66p.

Johnson, M. E., Chen, C. M., \& Jaeggi, J. J. (2001). Effect of rennet coagulation time on composition, yield, and quality of reduced-fat cheddar cheese. J. Dairy Sci., 84, 1027-1033.

O' Connor, C. B. (1993). Traditional cheese making manual. ILCA (International Livestock Centre for Africa), Addis Ababa, Ethiopia. Available from: www.fao.org/sd/erp/tosolkit/BOOKS/

Turkoglu, H., Ceylan, Z. G., \& Dayisoylu, K.S. (2003). The microbiology and chemical quality of Orgu cheese produced in Turkey. Park. J. Nutr., 2, 92-94.

Walstra, P. (1993). The Syneresis of curd. In P. F. Fox (Ed.), Cheese: Chemistry, physics and microbiology. Elsevier Appl. Sci., 1, 141-191. 